\title{
Pengaruh Kemampuan Penalaran Matematis dengan Model Pembelajaran Double Loop Problem Solving terhadap Hasil Belajar Siswa
}

\author{
Irfawandi Samad $^{1 *}$, Muhammad Ali $\mathrm{P}^{1}$, Muhammad Assaibin ${ }^{1}$ \\ 1. Pendidikan Matematika, Fakultas Keguruan dan Ilmu Pendidikan, Universitas Al Asyariah Mandar \\ *e-mail: ippank05@gmail.com \\ (Received: 08-09-2021; Reviewed: 16-09-2021; Accepted: 18-09-2021)
}

\begin{abstract}
Abstrak
Tujuan penelitian ini adalah untuk mengetahui pengaruh model pembelajaran double loop problem solving terhadap penalaran matematis siswa pada materi bangun ruang. Pada penelitian ini ditarik sampel sebanyak dua kelas, dengan jumlah peserta didik sebanya 67 peserta didik. Penelitian ini merupakan penelitian eksperimen dengan rancangan yang digunakan adalah eksperimen semu (Quasi Exsperimental Research).Penelitian ini melibatkan dua kelas yaitu kelas eksperimen dan kelas kontrol, dimana kedua kelas ini diberikan perlakuan yang berbeda. Untuk mengetahui pengaruh model pemelajaran double loop problem solving terhadap penalaran matematis siswa kelas VIII SMP Negeri 3 Campalagian. Dilihat pada pengujian hipotesis dilakukan dengan melihat hasil uji-t. Berdasarkan uji-t diperoleh nilai $t_{\text {hitung }}$ sebesar 2,204. Sedangkan untuk nilai $t_{\text {tabel }}$ sebesar 1,67 yang berarti bahwa $t_{\text {hitung }}>t_{\text {tabel }}$ yaitu 2,204 $>1,67$. Hal ini menunjukkan bahwa $H_{0}$ ditolak dan $H_{1}$ diterima, bila ditinjau dari nilai taraf signifikan, $H_{1}$ diterima apabila Sig $<\alpha$ yaitu $0,032<0,05$. dengan demikian dapat disimpulkan bahwa pembelajaran dengan Penerapan model pemelajaran double loop problem solving terhadap penalaran matematis dalam Pembelajaran Matematika Pada Peserta didik kelas VII SMP Negeri 3 Campalagian, berpengaruh terhadap hasil belajar siswa, dalam pelaksanaan pembelajaran dan pengamatan aktivitas siswa. Sehingga bisa diterapkan di sekolah.
\end{abstract}

Kata kunci; Pengaruh, double loop problem solving, penalaran matematis

\section{Abstract}

The purpose of this study was to determine the effect of the double loop problem solving learning model on students' mathematical reasoning on the material of building space. In this study, a sample of two classes was drawn, with a total of 67 students. This research is an experimental study with a quasi-experimental design (Quasi Experimental Research). This research involves two classes, namely the experimental class and the control class, where these two classes are given different treatment. To determine the effect of the double loop problem solving learning model on the mathematical reasoning of class VIII students of SMP Negeri 3 Campalagian. Judging from the hypothesis testing is done by looking at the results of the t-test. Based on the t-test, the t_count value is 2.204. Meanwhile, the value of t_table is 1.67, which means that t_count>t_table is 2.204>1.67. This shows that $H_{-} 0$ is rejected and $H_{-} 1$ is accepted, when viewed from the value of the significant level, $H_{-} 1$ is accepted if Sig $<\alpha$ is 0.032 $<0.05$. Thus, it can be concluded that learning by applying the double loop problem solving learning model to mathematical reasoning in Mathematics Learning in Grade VII students of SMP Negeri 3 Campalagian, has an effect on student learning outcomes, in implementing learning and observing student activities. So it can be applied in schools.

Keywords; Influence, double loop problem solving, mathematical reasoning

\section{PENDAHULUAN}

Pendidikan di Indonesia diberikan melalui mata pelajaran yang saling berkaitan dan saling terintegrasi menjadi satu kesatuan.Salah satu mata pelajaran yang diajarkan di Indonesia 
adalah Matematika. Matematika dapat diaplikasikan baik secara langsung maupun tidak langsung dalam bidang lain, seperti ekonomi, sains, teknologi, dan sebagainya. Pada saat mengembangkan kemampuan penalaran Matematis materi bangun ruang, setiap guru dihadapkan pada siswa yang memiliki karakteristik yang berbeda-beda antara satu dengan yang lainnya. Salah satu hal yang harus diperhatikan oleh guru dalam mengajar adalah mengenal anak didik, mengetahui kemampuannya, minat dan keterbatasannya, gaya belajarnya agar apa yang diberikan dan cara penyampaian materi pelajaran dapat disesuaikan dengan keadaan anak didik.

Berdasarkan hasil observasi yang telah dilakukan di SMP Negeri 3 Campalagian diketahui siswa yang jika diberikan contoh pada materi bangun ruang berkaitan dengan kehidupan sehari hari mereka ada sebagian siswa kurang dapat memahami apa yang dijelaskan oleh guru sedangkan contoh secara tertulis yang diberikan oleh guru kepada siswa terkait dengan lingkungan mereka sendiri.

Dengan adanya kemampuan penalaran matematis, siswa dapat mengungkapkan ide-ide matematikanya yang mengacu pada konfigurasi karakter gambar atau diagram, situasi kehidupan nyata, bahasa lisan, dan simbol tertulis yang berfungsis sebagai alat untuk mencari solusi dari interpretasi pemikiran peserta didik hingga adanya masalah.

Sehingga model pembelajaran Double Loop Problem Solving ini mempunya ciri utama yaitu pembelajaran berpusat pada pemberian masalah yang dibahas oleh siswa, dalam menyelesaikan permasalahan dalam model pembelajaran ini lebih menekankan tentang apa informasi yang dikumpulkan, bukan pada proses yang lebih efisien.

Menurut Yuspriyanti dalam (Lucky, 2015) secara umum langkah-langkah model pembelajaran DLPS (Double Loop Problem Solving) sebagai berikut:

a. Mengidentifikasi masalah, tidak hanya gejalanya. Pada tahap ini, deteksi yang dilakukan mencakup segala sesuatu yang menjadi faktor dari masalah yang sedang dihadapi;

b. Mendeteksi penyebab langsung, dan secara cepat menerapkan solusi sementara.Penyebab langsung ini lebih jelas, oleh karena itu mudah dideteksi dan dapat dicari solusinya untuk diterapkan secara cepat;

c. Mengevaluasi keberhasilan dari solusi sementara.Pada tahap ini dilakukan evaluasi seberapa besar keefektifan dan tingkan keberhasilan dari solusi sementara yang sudah diterapkan

d. Memutuskan apakah analisis akar masalah diperlukan atau tidak.Pada tahap ini diputuskan untuk melakukan analisis akar masalah atau cukup sampai tahap ini, dengan mempertimbangkan hasil evaluasi yang dilakukan sebelumnya;

e. Jika dibutuhkan, dilakukan deteksi terhadap penyebab masalah yang levelnya lebih tinggi. Penyebab yang dicari levelnya lebih tinggi dari penyebab yang telah ditemukan sebelumnya;

f. Merancang solusi akar masalah.Solusi yang dirancang tentunya bukan solusi semen-tara lagi, namun solusi yang dapat menyelesaikan masalah hingga tuntas

Menurut Adams, dalam (Laily, 2014)" Matematika itu seperti membaca, matematika merupakan keterampilan yang penting dalam kehidupan sehari-hari. Penalaran matematis adalah 
sesuatu yang dilakukan semua orang, mulai dari perhitungan sederhana sampai perhitungan yang rumit. Kemampuan untuk menggunakan keterampilan penalaran sangat bervariasi" (Rahmawati, 2013). Agar kemampuan penalaran siswa lebih berkembang, maka selama proses pembelajaran berlangsung diharapkan siswa terlibat secara aktif dalam melakukan aktivitas matematika, misalnya siswa melakukan diskusi dengan rekannya maupun dengan guru mengenai permasalahan matematika sehingga dapat mengkonstruksi dan mengevaluasi argumen-argumen mereka sendiri maupun argumen rekannya, serta dapat melakukan generalisasi saat penarikan kesimpulan.

\section{Metode}

Penelitian ini merupakan penelitian eksperimen dengan rancangan yang digunakan adalaheksperimen semu (Quasi Exsperimental Research) .Penelitian ini melibatkan dua kelas yaitu kelaseksperimen dan kelas kontrol, dimana kedua kelas ini diberikan perlakuan yang berbeda. Untuk mengetahui pengaruh model pemelajaran double loop problem solving terhadap penalaran matematis siswa kelas VIII SMP Negeri 3 Campalagian diperoleh dari tes yang dilakukansebanyak dua kali yaitu sebelum (pretest) dan sesudah perlakuan (posttest) (Kenny,1975).

Desain penelitian yang digunakan adalah Nonequivalent ControlGroup Design [Setyaningrum, 2019].Rancangan ini terdiri atas dua kelompok yang keduanya ditentukan secara acak. Sebelum dilakukan penelitian kedua kelompok diberikan tes awal (Pretest) dan setelah dilakukan penelitian kedua kelompok diberikan tes akhir (Postest), untuk lebih jelasnya rancangan penelitian tersebut dinyatakan dalam tabel berikut: Tabel 1,1 pengelompokan kelas eksprimen dan kelas kontrol

\begin{tabular}{|l|l|l|l|}
\hline Kelompok & Pre-test & Perlakuan & post-test \\
\hline Ekspremin & $\mathrm{O}_{1}$ & $X$ & $\mathrm{O}_{2}$ \\
\hline kontrol & $\mathrm{O}_{3}$ & $\mathrm{C}$ & $\mathrm{O}_{4}$ \\
\hline
\end{tabular}

Populasi adalah wilayah generalisasi yang terdiri atas objek / sabjek yang mempunyai kualitas dan karakteristik tertentu yang ditetapkan oleh peneliti untuk dielajari kemudian ditarik suatu kesimpulan (Sugiyono, 2016 ). Populasi dalam penelitian ini adalah seluruh peserta didik kelas VII SMP Negeri 3 Campalagian. Dari Hasil Observasi pada sekolah yang menjadi lokasi penelitian diketahui bahwa, jumlah keseluruhan jumlah peserta didik kelas VII SMP Negeri 3 Campalagian sebanyak 99 peserta didik terdiri dari 3 kelas. Pada penelitian ini ditarik sampel sebanyak dua kelas, dengan jumlah peserta didik sebanya 67 peserta didik.

Teknik Analisis Data Untuk menganalisis data hasil penelitian, maka digunakan teknik analisisstatistik deskriptif dan analisis statistik inferensial.. Uji normalitas dimaksudkan bahwa data sampel berasal dari populasi yang berdistribusi normal dengan menentukan taraf signifikansi uji $\alpha=0$, 05. Uji homogenitas dilakukan untuk mengetahui apakah sampel yang diteliti memiliki variasi yang homogen atau tidak pada taraf signifuikansi $\alpha=0,05$

Untuk keperluan penguji statistik maka hipotesis statistik dirumuskan sebagai berikut:

$H_{0}: \mu_{1}=\mu_{2}$

$H_{1}: \mu_{1} \neq \mu_{2}$ 


$$
\begin{aligned}
& \text { Keterangan : } \\
& \mu_{1}= \text { skor rata-rata kemampuan penalaran matematis siswa kelas eksperimen yang } \\
& \text { diajarkan dengan menggunakan model double loop problem solving } \\
& \mu_{2}= \text { skor rata-rata kemampuan penalaran matematis siswa kelas kontrol } \\
& \text { yang diajarkanmenggunakan model Pembelajaran Langsung }
\end{aligned}
$$

Hipotesis $H_{0}$ ditolak jika sig $<\alpha$, berarti terdapat perbedaan rata-rata Penalaran sistematis siswa antara kelas eksperimen dengan kelas control.

\section{Hasil}

Dari hasil analisis statistika deskriptif, maka statistik skor hasil belajar matematika peserta didik untuk kelompok eksperimen dan kelompok kontol dirangkum dalam tabel berikut.

Tabel 3.1 Hasil analisis statistika deskriptif

\begin{tabular}{lcc}
\hline \multicolumn{1}{c}{ Statistics } & PostTest_Eks & Post Tes_Kon \\
\hline Mean & 73.33 & 66.17 \\
\hline Median & 72.50 & 65.00 \\
\hline Mode & $70^{\mathrm{a}}$ & $65^{\mathrm{a}}$ \\
\hline Std. Deviation & 11.842 & 13.306 \\
\hline Range & 50 & 45 \\
\hline Minimum & 45 & 40 \\
\hline Maximum & 95 & 85 \\
\hline
\end{tabular}

Berdasarkan tabel 3.1 di atas diperoleh informasi bahwa skor rata-rata hasil belajar matematika peserta didik yang diajar dengan menggunakan Model Pembelajaran Double Loop Problem Solving adalah 73,33. Dengan standar deviasi 11.842. Skor Terendah yang diperoleh adalah 45, dan Skor tertinggi yang diperoleh adalah 95 dari skor ideal 100 yang mungkin dicapai. Pada kelas diperoleh informasi bahwa skor rata-rata hasil belajar matematika peserta didik yang diajar dengan Model konvensional adalah 66,17 dengan standar deviasi 13,306, Skor Terendah yang diperoleh adalah 40 dan Skor tertinggi yang diperoleh adalah 95 dari skor ideal 100 yang mungkin dicapai.

Indikator yang dibandingkan pada analisis inferensial adalah hasil belajar peserta didik berdasarkan hasil analisis inferensial.Analisis inferensial yang dilakukan diawali dengan beberapa uji prasyarat untuk data pree-test, danpost-test, diantaranya uji normalitas dan uji homogenitas varians.Uji normalitas dilakukan untuk mengetahui apakah data bersistribusi normal atau tidak sedangkan uji homogenitas varian dilakukan untuk mengatahui kehomogenan varians dari populasi. 
Pengujian normalitas data dilakukan terhadap data hasil belajar pada kelas kontrol dan kelas eksperimen. Uji tersebut dilakukan dengan uji Kolmogorov-Smirnov ${ }^{\mathrm{a}}$ menggunakan program SPSS 20.0 for Windows dengan taraf signifikansi 0,05.

Uji normalitas dilakukan untuk mengetahui apakah populasi yang diteliti berdistribusi normal atau tidak.

Hipotesis yang akan diuji ialah

$H_{0}$ : Data berasal dari populasi yang normal

$H_{1}$ : Data berasal dari populasi yang tidak normal

Tabel 3.2. Tes Nomalitas untuk Kelompok Eksperimen dan Kelompok Kontrol

\section{Tests of Normality}

\begin{tabular}{|c|c|c|c|}
\hline & \multicolumn{2}{|c|}{ Kolmogorov-Smirnov ${ }^{a}$} & \\
\hline & Statistic & Df & Sig. \\
\hline PostTest_Eks & .123 & 30 & $.200^{*}$ \\
\hline PostTes_Kon & .099 & 30 & $.200^{*}$ \\
\hline
\end{tabular}

Pada kelas eksperimen dan kelompok kontrol diperoleh nilai signifikan sebesar 0,200 yang berarti bahwa signifikansi yang diperoleh $>\alpha$ yaitu $0,200>0,05$ maka $H_{0}$ diterima dan $H_{1}$ ditolak berarti data berasal dari populasi normal atau data skor hasil belajar matematika peserta didik yang diajar dengan Model Pembelajaran Double Loop Problem Solving berdistribusi normal dan begitu pula dengan model pembelajaran yang konvensional.

Untuk lebih jelasnya dapat dilihat pada gambar 3.1 gambar grafik posttes kelas ekspromen dan kelas kontrol sebagai berikut :
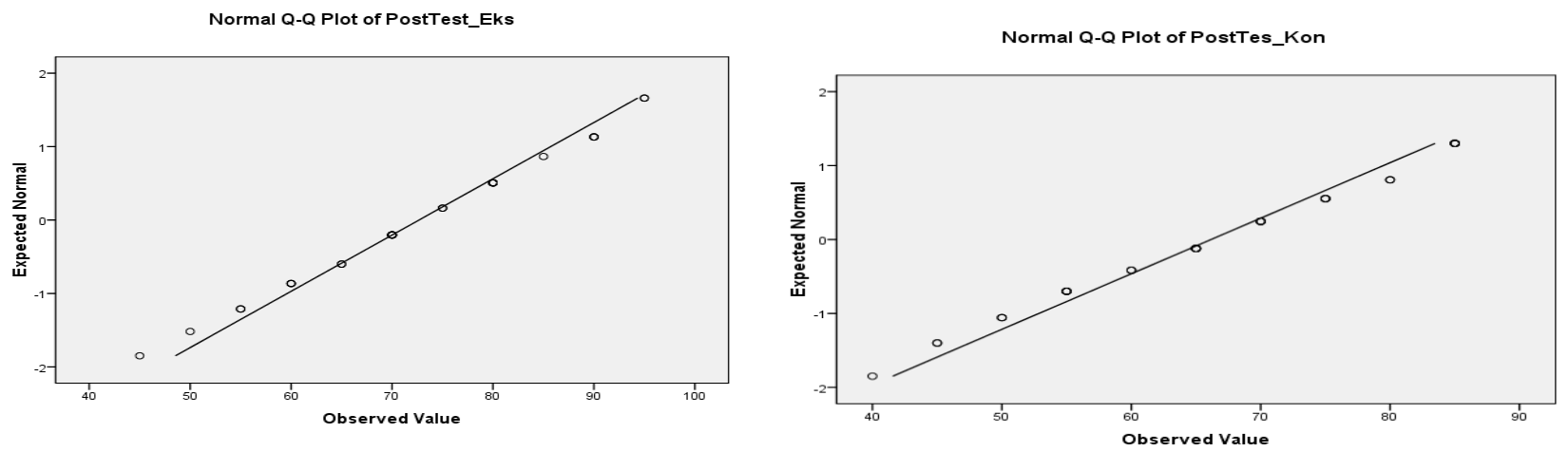

Dari gambar 3.1 terlihat garis lurus dari kiri bawah ke kanan atas.Tingkat penyebaran titik di suatu garis menunjukkan normal tidaknya suatu data."Jika suatu distribusi data normal, maka data akan tersebar di sekeliling garis".Grafik di atas terlihat bahwa data tersebar di sekeliling garis lurus. Sehingga dapat disimpulkan bahwa data skor post test untuk peserta didik kelas eksperimen dan kontol berasal dari populasi yang berdistribusi normal.

Uji homogenitas dilakukan untuk mengetahui apakah kelompok-kelompok sampel yang diambil berasal dari populasi dengan variansi yang sama atau homogen. 
Hipotesis yang akan diuji ialah

$H_{0}$ : Variansi pada tiap kelompok sama(homogen)

$H_{1}$ : Variansi pada tiap kelompok tidak sama (tidak homogen)

Tabel 3.3. Uji homogenitas

\begin{tabular}{llrrrr}
\hline \multicolumn{7}{c}{ Test of Homogeneity of Variance } & & & & \\
\hline & \multicolumn{1}{c}{ Statistic } & & Sig. \\
\hline \multirow{2}{*}{ Nilai } & Based on Mean & .718 & 1 & 58 & .400 \\
\cline { 2 - 6 } & Based on Median & .626 & 1 & 58 & .432 \\
\cline { 2 - 6 } & Based on Median and with adjusted df & .626 & 1 & 57.809 & .432 \\
\cline { 2 - 6 } & Based on trimmed mean & .740 & 1 & 58 & $3[\mathrm{a} 1][\mathrm{a} 2]$ \\
\hline
\end{tabular}

Berdasarkan hasil analisis data, dengan taraf signifikansi $\alpha=0,05$, Uji homogenitas dengan SPSS 20,0 For Windows diperoleh nilai signifikansi sebesar 0,400 yang berarti bahwa signifikansi yang diperoleh $>\alpha$ yaitu $0,400>0,05$ maka $H_{0}$ diterima dan $H_{1}$ ditolak berarti variansi setiap sampel sama (homogen). Hal ini menunjukkan bahwa data skor hasil belajar matematika peserta didik untuk kedua kelompok perlakuan berasal dari populasi yang homogen.

Hipotesis yang akan yang diuji dengan menggunkan statistik uji-t adalah pembelajaran dengan Model Pembelajaran Double Loop Problem Solving berpengaru terhadap hasil belajar matematika peserta didik kelas VII SMP Negeri 3 Campalagian jika dibandingkan dengan pembelajaran Model konvensional, hipotesis dalam penelitian ini adalah sebagai berikut :

Tabel 3.4. Uji t (uji Hipotesis)

Independent Samples Test

\begin{tabular}{ccc}
\multicolumn{4}{c}{ t-test for Equality of Means } \\
\hline $\mathrm{T}$ & Df & Sig. (2-tailed)
\end{tabular}

\begin{tabular}{llccc} 
Nilai & Equal variances assumed & 2.204 & 58 & .032 \\
\cline { 2 - 5 } & Equal variances not assumed & 2.204 & 57.230 & .032 \\
\hline
\end{tabular}

Berdasarkan hasil analisis data, kedua kelompok berdistribusi normal dan homogen, sehingga pengujian hipotesis dilakukan dengan menggunakan statistik uji-t. Berdasarkan statistik uji-t dengan SPSS 20,0 For Windows diperoleh nilai $t_{\text {hitung }}$ sebesar 2,204. Sedangkan untuk nilai $t_{\text {tabel }}$ sebesar 1,67 yang berarti bahwa $t_{\text {hitung }}>t_{\text {tabel }}$ yaitu $2,204>1,67$. Hal ini menunjukkan bahwa $H_{0}$ ditolak dan $H_{1}$ diterima, bila ditinjau dari nilai taraf signifikan, $H_{1}$ diterima apabila $\mathrm{Sig}<\alpha$ yaitu $0,032<0,05$. dengan demikian dapat disimpulkan bahwa pembelajaran dengan Penerapan Model Pembelajaran Double Loop Problem Solving berpengaru terhadap hasil belajar matematika peserta didik kelas VII SMP Negeri 3 Campalagian. 


\section{Pembahasan}

Pada pengujian hipotesis di peroleh bahwa hasil dari pengujian satatistik deskriptif memperlihatkan hasil peningkatan yang signifikan pada kelas eksperimen di bandingkan kelas kontrol, Indikator yang dibandingkan pada analisis inferensial adalah hasil belajar peserta didik berdasarkan hasil analisis inferensial.Analisis inferensial yang dilakukan diawali dengan beberapa uji prasyarat untuk data pree-test, dan post-test, diantaranya uji normalitas dan uji homogenitas varians.Uji normalitas dilakukan untuk mengetahui apakah data bersistribusi normal atau tidak sedangkan uji homogenitas varian dilakukan untuk mengatahui kehomogenan varians dari populasi. Dari hasil uji t, dapat disimpulkan bahwa pembelajaran dengan Penerapan Model Pembelajaran Double Loop Problem Solving berpengaru terhadap hasil belajar matematika peserta didik kelas VII SMP Negeri 3 Campalagian.

\section{Kesimpulan}

Penelitian ini melibatkan dua kelas yaitu kelas eksperimen dan kelas kontrol, dimana kedua kelas ini diberikan perlakuan yang berbeda. Untuk mengetahui pengaruh model pemelajaran double loop problem solving terhadap penalaran matematis siswa kelas VIII SMP Negeri 3 Campalagian. Dilihat pada pengujian hipotesis dilakukan dengan melihat hasil uji-t. Berdasarkan uji-t diperoleh nilai $t_{\text {hitung }}$ sebesar 2,204. Sedangkan untuk nilai $t_{\text {tabel }}$ sebesar 1,67 yang berarti bahwa $t_{\text {hitung }}>t_{\text {tabel }}$ yaitu $2,204>1,67$. Hal ini menunjukkan bahwa $H_{0}$ ditolak dan $H_{1}$ diterima, bila ditinjau dari nilai taraf signifikan, $H_{1}$ diterima apabila $\operatorname{Sig}<\alpha$ yaitu $0,032<0,05$. dengan demikian dapat disimpulkan bahwa pembelajaran dengan Penerapan model pemelajaran double loop problem solving terhadap penalaran matematis dalam Pembelajaran Matematika Pada Peserta didik kelas VII SMP Negeri 3 Campalagian berpengaruh dalam pelaksanaan pembelajaran dan pengamatan aktivitas siswa. Sehingga bisa diterapkan di sekolah.

\section{Referensi}

Kenny, David A. A quasi-experimental approach to assessing treatment effects in the nonequivalent control group design. Psychological Bulletin, 1975, 82.3: 345.

Lucky, H. J. (2015). Penerapan Double Loop Problem Solving Untuk Meningkatkan Kemampuan Literasi Matematis Level 3 Pada Siswa Kelas VIII SMPN 27 Bandung. Lemma, 2(1), 52-62

Laily, I. F. (2014). Hubungan kemampuan membaca pemahaman dengan kemampuan memahami soal cerita matematika sekolah dasar. Eduma: Mathematics Education Learning and Teaching, 3(1).

Noeraini, Irma Ayu; SUGIYONO, Sugiyono. PENGARUH TINGKAT KEPERCAYAAN, KUALITAS PELAYANAN, DAN HARGATERHADAP KEPUASAN PELANGGAN JNE SURABAYA. Jurnal Ilmu dan Riset Manajemen (JIRM), 2016, 5.5.

Setyaningrum, E. (2019). Meningkatkan kemampuan penalaran dan self confidence matematis siswa melalui model pembelajaran double loop problem solving (Doctoral dissertation, UIN Sunan Gunung Djati Bandung). 
Rahmawati, F. (2013). Pengaruh Pendekatan Pendidikan Realistik Matematika dalam Meningkatkan Kemampuan Komunikasi Matematis Siswa Sekolah Dasar. Prosiding SEMIRATA 2013, 1(1). 